\title{
A New Treatment Option for Vestibular Migraine: Onabotulinum Toxin Type A
}

\author{
Vestibüler Migren için Yeni Bir Tedavi Seçeneği: Onabotulinum Toksin Tip-A
}

\author{
(D) Reyhan Sürmeli1, (1) Tülay Erden Habeșoğlu22 \\ 1 University of Health Sciences Turkey, Ümraniye Training and Research Hospital, Clinic of Neurology, İstanbul, Turkey \\ 2University of Health Sciences Turkey, Fatih Sultan Mehmet Training and Research Hospital, Clinic of Otolaryngology, İstanbul, Turkey
}

\begin{abstract}
Introduction: Vestibular migraine is a clinical entity characterised by dizziness. Additionally, it has no proven treatment options, and the goal is to control vestibular symptoms by reducing migraine attacks. This study aimed to investigate the effect of onabotulinum toxin type A in reducing vestibular migraine symptoms.

Methods: Between 2014 and 2019, the charts of 80 patients with migraine who received onabotulinum toxin type $A$ treatment were collected. Among them, 22 patients who met the criteria of vestibular migraine were included in the study. The treatment outcomes of these patients were investigated. Migraine Disability Assessment scale (MIDAS), Visual Analogue scale (VAS) and Dizziness Handicap index (DHI) were used for evaluation. Pre-treatment and post-treatment values were compared.
\end{abstract}

Results: The mean age of the patients was 41.5 years. When MIDAS, DHI and VAS scores were compared, the post-treatment scores were found to be statistically significantly lower than the pre-treatment scores $(p<0.05)$.

Conclusion: Botulinum toxin treatment may be promising in patients with vestibular migraine. The limitation of this study is our relatively small group of patients. Therefore, there is a need for prospective work with a larger group of patients.

Keywords: Vestibular migraine, Onabotulinum toxin type A, dizziness, headache

\section{öZ}

Amaç: Vestibüler migren, migren hastalarında baș dönmesi ile karakterize klinik bir durumdur. Ek olarak, kanıtlanmış bir tedavi seçeneği bulunmamakta olup, hedef, migren ataklarını azaltarak vestibuler semptomları kontrol altına almaktır. Bu çalışmanın amacı Onabotulinum toksin tip A'nın vestibüler migren hastalarının semptomlarını azaltmadaki etkisini araștırmaktır.

Yöntemler: 2014-2019 yılları arasında migren tanısıyla onabotulinum toksin tip A tedavisi alan olan 80 hastanın verileri retrospektif olarak toplandı. Çalıșmaya, vestibüler migren kriterlerini karșılayan 22 hasta dahil edildi. Bu hastaların tedavi sonuçları araștırıldı. Migren Engellilik Değerlendirme ölçeği (MIDAS), Görsel Analog ölçeği (VAS) ve Dizziness Handikap indeksi (DHI) değerlendirildi. Tedavi öncesi ve tedavi sonrası değerler karşılaştırıldı.

Bulgular: Hastaların yaş ortalaması 41,5 olarak bulundu. MIDAS, DHI ve VAS skorları karșılaștırıldığında, tedavi sonrası skorların tedavi öncesi skorlardan istatistiksel olarak anlamlı derecede düșük olduğu saptandı. $(p<0,05)$.

Sonuç: Vestibüler migren hastalarında botulinum toksin tedavisi umut verici olabilir. Bu çalışmanın kısıtlılı̆̆ı nispeten küçük hasta grubumuzdur. Bu nedenle, daha büyük hasta grubuyla ileriye dönük bir çalıșmaya ihtiyaç vardır.

Anahtar Kelimeler: Vestibülar migren, onabotulinum toxin tip-A, dengesizlik, baş ağrısı

\section{Introduction}

Migraine is a chronic multifactorial disease. Headache may be accompanied by photophobia, phonophobia, nausea and vomiting $(1,2)$. Although the relationship between migraine and vertigo was described by Cal et al. (3) and Liveing (4), the increase in research on this issue began after Kayan and Hood's (5) comprehensive study in 1984. The term "vestibular migraine" was first used by Dieterich and Brandt (6) in 1999.
Vestibular migraine is a clinical entity characterised by dizziness. It was detected in $13 \%$ of patients who were evaluated in balance clinics due to vertigo and imbalance complaints (7). A detailed history is crucial for diagnosis. It may be seen at any age but is more common in women $(7,8)$. Patients typically have spontaneous or positional vertigo, and they also have head motion intolerance (8). Vestibular migraine should be considered in patients with vertigo who are admitted with a diagnosis of migraine or headaches after excluding benign paroxysmal positional 
vertigo, which is the most common cause of vertigo. Also, vestibular migraine causes depression and anxiety at a higher rate than classical migraine (9). For diagnosis, the Bárány Society and International Headache Society migraine classification sub-committee have published a new classification in 2013 (10). There have been no proven treatment options for vestibular migraine; therefore, the goal is to control vestibular symptoms by reducing migraine attacks. Drugs for migraine prophylaxis, such as beta-blockers, antidepressants, calcium channel blockers, pizotifen, topiramate, valproic acid and lamotrigine, have also been reported to be effective for vestibular migraine $(11,12)$.

Botulinum toxin type $\mathrm{A}$ has been shown to be effective in treating chronic migraine (13-16). For this reason, this study aimed to investigate the effect of onabotulinum toxin type $A$ in reducing symptoms of patients with vestibular migraine.

\section{Methods}

The charts of 80 patients with migraine who received onabotulinum toxin type A treatment between 2014 and 2019 in the Ümraniye Training and Research Hospital, Clinic of Neurology were collected. The study protocol was reviewed and approved by the Ethics Committee of University of Health Sciences Turkey, Ümraniye Training and Research Hospital (reference number: 11066, approval date: 27.07.2016). Informed consent was obtained from the patients.

We retrospectively reviewed the data of patients who had no response to medical treatment, did not comply with medications or did not take medicine because of side effects and, as a result, treated with onabotulinum toxin type A treatment. A total of 22 patients who met the criteria for vestibular migraine (10) were included in the study. Patients who did not meet the criteria of vestibular migraine or receive onabotulinum toxin type A were excluded from the study. The treatment outcomes of these patients were investigated. Migraine Disability Assessment scale (MIDAS), Visual Analogue scale (VAS) for vertigo symptoms and Dizziness Handicap index (DHI) were used for evaluation. Pre-treatment and post-treatment values were compared.

Botulinum toxin application was carried out following the Phase III Research Evaluating Migraine Prophylaxis Therapy protocol $(17,18)$. According to the onabotulinum toxin type A application technique, 100 $\mathrm{MU}$ of onabotulinum toxin type A was diluted with $2.0 \mathrm{~mL}$ of saline, yielding a concentration of $5 \mathrm{MU} / 0.1 \mathrm{~mL}$. Each area of application site was injected with $5 \mathrm{MU}$ onabotulinum toxin type A. The injection protocol consisted of 31 fixed points in the following muscles: frontalis $20 \mathrm{MU}$ (four sites), corrugators $10 \mathrm{MU}$ (two sites), procerus $5 \mathrm{MU}$ (1 site), occipitalis $30 \mathrm{MU}$ (six sites), temporalis $40 \mathrm{MU}$ (eight sites), trapezius $30 \mathrm{MU}$ (six sites) and cervical paraspinal muscle group $20 \mathrm{MU}$ (four sites). As per this protocol, a total of $155 \mathrm{MU}$ onabotulinum toxin type A was applied. The recommended doses ranged from 155 to 195 units. Additional $40 \mathrm{MU}$ can be applied to the temporalis, occipitalis or trapezius muscles $(19,20)$.

\section{Statistical Analysis}

Statistical analysis was performed by IBM SPSS Statistics Version 20. Mean, median, standard deviation, and maximum and minimum values were calculated for numeric variables. The mean value for data with a normal distribution and the median value for data that did not conform to the normal distribution were used for statistical analysis. Wilcoxon signed-rank test determined variables that did not meet the normal distribution. Friedman test was used for statistical analysis of dependent triple groups. Bonferroni post-hoc test determined the statistical difference between the groups. The statistical significance level was accepted as $p<0.05$.

\section{Results}

All the patients included in the study were women. The age of the patients ranged from 18 to 67 years, with a mean of $41.5 \pm 10.22$ years (Table 1).

The median pre-treatment and 3 months post-treatment MIDAS scores of the patients were $50.9 \pm 6.33$ and $13.18 \pm 3.45$, respectively, indicating a statistically significant improvement $(p<0.05$, Table 2, Figure 1).

The mean pre-treatment and post-treatment $\mathrm{DHI}$ scores were $59.5 \pm 4.24$ and $8.81 \pm 1.91$, respectively, and the improvement was also statistically significant $(p<0.05$, Table 2, Figure 2).

Table 1. Demographic features of patients $(n=22)$

\begin{tabular}{|l|l|l|}
\hline Demographic features & $\mathbf{n = 2 2}$ \\
\hline Gender (F/M), $\mathbf{n}$ & $22 / 0$ \\
\hline Age (year) & Mean \pm SD & $41.54 \pm 10.22$ \\
\hline $\begin{array}{l}\text { Duration of disease } \\
\text { (year) }\end{array}$ & Median (range) & $42(18-67)$ \\
\hline
\end{tabular}

$\mathrm{n}$ : number of samples, M: male, F: female, SD: standard deviation

\begin{tabular}{|c|c|c|c|c|}
\hline \multicolumn{2}{|c|}{ Number of subjects } & $\begin{array}{l}\text { Before treatment } \\
n=22\end{array}$ & $\begin{array}{l}\text { After } 3 \text { months of treatment } \\
n=22\end{array}$ & \multirow{2}{*}{$\begin{array}{l}p \\
{ }^{a}<0.001 *\end{array}$} \\
\hline \multirow{2}{*}{ MIDAS } & Mean \pm SD & $50.90 \pm 6.33$ & $13.18 \pm 3.45$ & \\
\hline & Median (range) & $50(42-65)$ & $12(10-20)$ & - \\
\hline \multirow{2}{*}{ DHI } & Mean \pm SD & $59.54 \pm 4.27$ & $8.81 \pm 1.91$ & ${ }^{a}<0.001 *$ \\
\hline & Median (range) & $58(54-70)$ & $8(4-12)$ & - \\
\hline
\end{tabular}

MIDAS: Migraine Disability Assessment scale, DHI: Dizziness Handicap Inventory, SD: standard deviation, n: number of patients, a: Wilcoxon signed ranks test, *: $p<0.05$ 
The comparison of VAS scores between pre-treatment values and 1, 2 and 3 months post-treatment was statistically significant $(p<0.05)$. The statistical difference originated between the pre-treatment and posttreatment groups. There was no significant difference between the posttreatment groups (Table 3, Figure 3).

Also, the decrease in the number of post-treatment vestibular migraine attacks was statistically significant when compared with that in the pretreatment values $(p<0.01$, Table 4$)$.

\section{Discussion}

Vestibular migraine is a disease that can be seen at all ages mostly in women $(6,7,11)$. In our study, we observed that all patients were women between 18 and 67 years of age.

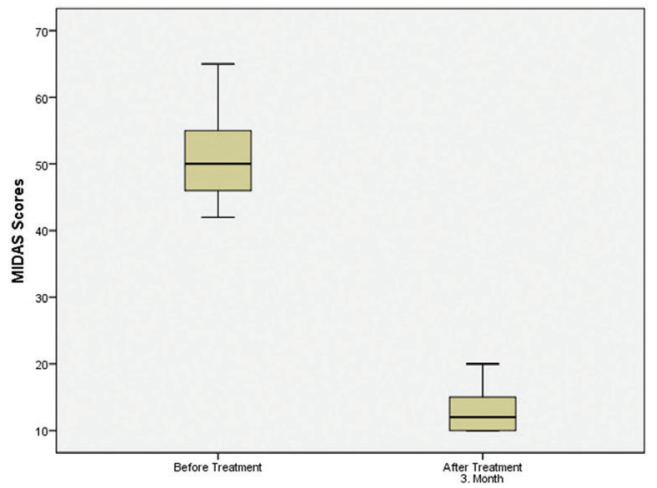

Figure 1. Pre-treatment and post-treatment Migraine Disability Assessment scale (MIDAS) scores of vestibular migraine patients $(p<0.05)$

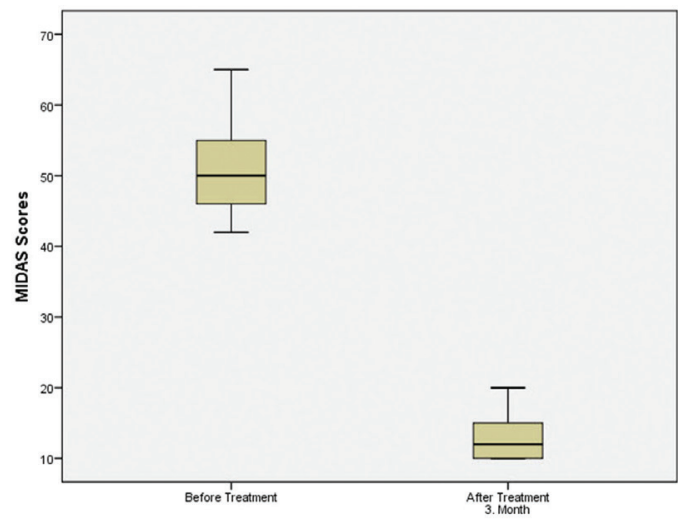

Figure 2. Pre-treatment and post-treatment Dizziness Handicap Inventory scores of vestibular migraine patients $(p<0.05)$

MIDAS: Migraine Disability Assessment scale
Treatment of vestibular migraine consists of acute attack management and prophylaxis, which are also the current protocols for migraines (21). Studies conducted in this context consist of retrospective chart reviews and case presentations, but there have been no randomised controlled studies yet.

In the study of Reploeg and Goebel (22), $72 \%$ of migraine patients with dizziness and imbalance symptoms reported improvement from prophylaxis. According to Salmito et al. (23), 80.9\% of vestibular migraine patients benefited from prophylaxis. In vestibular migraine prophylaxis, drugs such as beta-blockers, calcium channel blockers, anti-depressants and valproic acid are used (23). In another study, beta-blockers have been shown to be effective in vestibular migraine symptoms and headache (21). Johnson (24) conducted a retrospective study that investigated the efficacy of benzodiazepine, tricyclic anti-depressants, beta-blockers and selective serotonin reuptake inhibitors on patients with vestibular migraine symptoms and concluded that vertigo and dizziness were reduced in these patients. In a study by Baier et al. (25), 100 patients

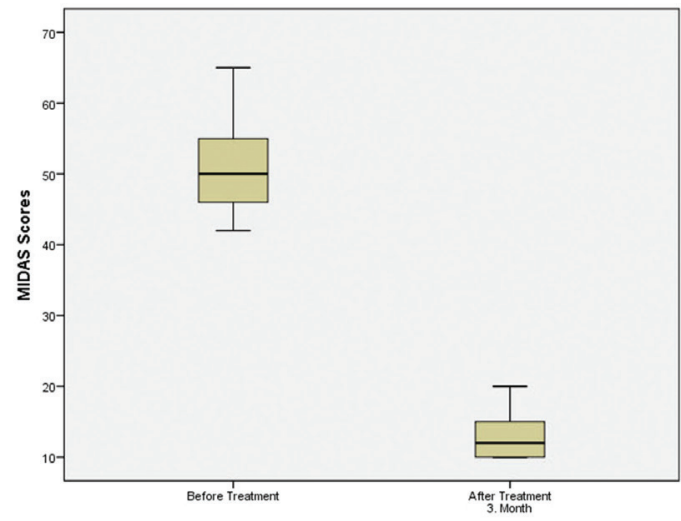

Figure 3. Pre-treatment and post-treatment Visual Analogue scale scores of vestibular migraine patients $(p<0.05)$

MIDAS: Migraine Disability Assessment scale

Table 4. Number of monthly episodes of vestibular migraine before and after botox administration

\begin{tabular}{|c|c|c|c|c|}
\hline \multirow{2}{*}{\multicolumn{2}{|c|}{ Number of subjects }} & $\begin{array}{l}\text { Before } \\
\text { treatment }\end{array}$ & $\begin{array}{l}\text { After } 3 \text { months } \\
\text { treatment }\end{array}$ & \multirow[t]{2}{*}{$\mathbf{p}$} \\
\hline & & $n=22$ & $n=22$ & \\
\hline \multirow{2}{*}{ Attack } & Mean $\pm S D$ & $10.5 \pm 2.44$ & $0.40 \pm 0.59$ & ${ }^{a}<0.001^{*}$ \\
\hline & Median (range) & $11(6-15)$ & $0(0-2)$ & - \\
\hline
\end{tabular}

SD: standard deviation, $\mathrm{n}$ : number of patients, a: Wilcoxon signed ranks test, *: $p<0.05$

Table 3. Assessment of Visual Analogue scale scores before and after 1, 2 and 3 of months of botox administration in patients with vestibular migraine

\begin{tabular}{|c|c|c|c|c|c|c|}
\hline \multirow{2}{*}{\multicolumn{2}{|c|}{ Number of subjects }} & Before treatment & $\begin{array}{l}\text { After } 1 \text { month of } \\
\text { treatment }\end{array}$ & $\begin{array}{l}\text { After } 2 \text { months of } \\
\text { treatment }\end{array}$ & $\begin{array}{l}\text { After } 3 \text { months of } \\
\text { treatment }\end{array}$ & \multirow{2}{*}{$p$} \\
\hline & & \multirow{2}{*}{$\begin{array}{l}n=22 \\
8.77 \pm 1.06\end{array}$} & \multirow{2}{*}{$\begin{array}{l}n=22 \\
2.72 \pm 0.45\end{array}$} & \multirow{2}{*}{$\begin{array}{l}n=22 \\
1.50 \pm 0.51\end{array}$} & \multirow{2}{*}{$\begin{array}{l}n=22 \\
0.40 \pm 0.50\end{array}$} & \\
\hline MAC & Mean $\pm S D$ & & & & & ${ }^{\mathrm{a}}<0.001^{*}$ \\
\hline S V & Median (Range) & $9(7-10)$ & $3(2-3)$ & $1(1-2)$ & $0(0-1)$ & - \\
\hline
\end{tabular}


investigated the effects of non-pharmacologic and pharmacologic agents such as beta-blockers (propranolol or metoprolol) and anti-convulsants (valproic acid, topiramate or lamotrigine) retrospectively. This study has shown that the improvement in frequency, duration and severity of vestibular episodes was the same as much as headache episodes. This effect was reported to be more prominent in pharmacological treatments (25). Celiker et al. (26) reported that in 37 migraine patients who were treated with valproic acid every day for 3 months, 13 of them had vertigo, 13 had dizziness, and 11 had no vestibular symptoms at all. Their migraine, vertigo and dizziness were improved. A study followed 10 patients with vertiginous migraine who were taking topiramate, which has been reported to be effective in treating migraine-related vertigo, for a mean of 9 months (27). Another retrospective study investigated the follow-up of 19 patients taking lamotrigine (28). Although a decrease in the frequency of vertigo episodes had been reported, there was no decrease in headache frequency in both of these studies.

Botulinum toxin inhibits acetylcholine release from presynaptic vesicles at the muscle nerve junction and leads to reversible muscular paralysis (29). The toxin is thought to inhibit central sensitisation by inhibiting the peripheral sensitisation of nociceptive fibres (30). In addition, it also inhibits pain mediators such as glutamate A, calcitonin gene-related peptide and substance $P$, thereby reducing pain signals (31). There are reports that botulinum toxin therapy in chronic migraine reduces pain and frequency of attacks $(17,32)$.

Although the widespread use of botulinum toxin for migraine prophylaxis has been accepted in the literature, to date, there has been no study investigating the effect of it as vestibular migraine prophylaxis. Here, we reviewed the charts of patients who received botulinum toxin treatment for chronic migraine, and among them, we collected data of the patients who met the criteria for vestibular migraine. Statistically significant improvements in MIDAS, DHI and VAS scores after onabotulinum toxin type A therapy were observed. Therefore, we considered the use of botulinum toxin as a promising treatment option for vestibular migraine patients.

\section{Conclusion}

In previous studies, the effects of pharmacological treatment on headache and vertigo attacks severity, frequency and duration were investigated in patients with vestibular migraine. The quality of the data in vestibular migraine management is relatively weak, although it has many treatment options in daily practice. Also, to date, there are no data about the use of botulinum toxin in vestibular migraine. The importance of our study is that it is the first paper to investigate botulinum toxin treatment in vestibular migraine patients. Our relatively small group of patients is the limitation of our work. Therefore, there is a need for prospective work with a larger group of patients. We believe that our study may lead to future work in this regard.

\section{Ethics}

Ethics Committee Approval: The study protocol was reviewed and approved by the Ethics Committee of University of Health Sciences Turkey, Ümraniye Training and Research Hospital (reference number: 11066, approval date: 27.07.2016).
Informed Consent: Informed consent was obtained from the patients.

Peer-review: Externally peer-reviewed.

Author Contributions: Concept - R.S.; Design - R.S.; Data Collection and/ or Processing - R.S; Analysis and/or Interpretation - T.E.H.; Literature Search - TE.H.; Writing - R.S.

Conflict of Interest: There is no conflict of interest between authors.

Financial Disclosure: The authors declared that this study received no financial support.

\section{References}

1. Bolay H, Bayazit YA, Gündüz B, Ugur AK, Akçali D, Altunyay S, et al. Subclinical dysfunction of cochlea and cochlear effer-ents in migraine: an otoacoustic emission study. Cephalalgia 2008; 28: 309-17.

2. Dash AK, Panda N, Khandelwal G, Lal V, Mann SS. Migraineand audiovestibular dysfunction: is there a correlation. Am J Otolaryngol 2008; 29: 295-9.

3. Cal R, Bahmad F Jr. Migraine associated with auditory-vestibular dysfunction. Braz J Otorhinolaryngol 2008; 74: 606-12.

4. Liveing E. On megrim, sick-headache, and some allied disorders. London, UK: Churchill; 1873.

5. Kayan A, Hood JD. Neuro-otological manifestations of migraine. Brain 1984; 107: 1123-42.

6. Dieterich M, Brandt T. Episodic vertigo related to migraine (90cases): vestibular migraine. J Neurol 1999; 246: 883-92.

7. Akdal G. Clinical Features of Migrainous Vertigo. J Neurol Sci Turk 2008; 15 : 92-5.

8. Neuhauser H, Lempert T. Vertigo and dizziness related to migraine: diagnostic challenge. Cephalalgia 2004; 24: 83-91.

9. Kutay Ö, Akdal G, Keskinoğlu P, Balcı BD, Alkın T. Vestibular migraine patients are more anxious than migraine patients without vestibular symptoms. J Neurol 2017; 264(Suppl 1): 37-41.

10. Headache Classification Committee of the International Headache Society. The International Classification of Headache Disorders, 3rd edition (beta version). Cephalalgia 2013; 33: 629-808.

11. Lempert T, Neuhauser $\mathrm{H}$, Daroff RB. Vertigo as a symptom of migraine. Ann $\mathrm{N}$ Y Acad Sci 2009; 1164: 242-51.

12. Fotuhi M, Glaun B, Quan SY, Sofare T. Vestibular migraine: a critical review of treatment trials. J Neurol 2009; 256: 711-16.

13. Silberstein S, Mathew $N$, Saper J, Jenkins $S$. Botulinum toxin type $A$ as a migraine preventive treatment. For the BOTOX Migraine Clinical Research Group. Headache 2000; 40: 445-50.

14. Mathew NT, Frishberg BM, Gawel M, Dimitrova R, Gibson J, Turkel C, et al. Botulinum toxin type A (BOTOX) for the prophylactic treatment of chronic daily headache: a randomized, double-blind, placebocontrolled trial. Headache 2005; 45: 293-307.

15. Silberstein SD, Stark SR, Lucas SM, Christie SN, Degryse RE, Turkel CC, et al. Botulinum toxin type $A$ for the prophylactic treatment of chronic daily headache: a randomized, double-blind, placebocontrolled trial. Mayo Clin Proc 2005; 80: 1126-37.

16. Silberstein SD, Göbel H, Jensen R, Elkind AH, Degryse R, Walcott JMCM, et. al. Botulinum toxin type $A$ in the prophylactic treatment of chronic tensiontype headache: a multicenter, double-blind, randomized, placebocontroled, parallel-group study. Cephalalgia 2006; 26: 790-800.

17. Aurora SK, Dodick DW, Turkel CC, DeGreyse RE, Silberstein SD, Lipton RB, et al. OnabotulinumtoxinA for treatment of chronic migraine: results from the 
double-blind, randomized, placebo-controlled phase of the PREEMPT 1 trial. Cephalalgia 2010; 30: 793-803.

18. Diener HC, Dodick DW, Aurora SK, Turkel CC, DeGreyse RE, Lipton RB, et al. OnabotulinumtoxinA for treatment of chronic migraine: results from the double-blind, randomized, placebo-controlled phase of the PREEMPT 2 trial. Cephalalgia 2010; 30: 804-14.

19. Silberstein SD, Blumenfeld AM, Cady RK, Turner IM, Lipton RB, Diener HC, et al. OnabotulinumtoxinA for treatment of chronic migraine: PREEMPT 24-week pooled subgroup analysis of patients who had acute headache medication overuse at baseline. J Neurol Sci 2013; 331: 48-56.

20. Whitcup SM, Turkel CC, DeGryse RE, Brin MF. Development of onabotulinumtoxinA for chronic migraine. Ann N Y Acad Sci 2014; 1329: 6780 .

21. Maione A. Migraine-related vertigo: diagnostic criteria and prophylactic treatment. Laryngoscope 2006; 116: 1782-86.

22. Reploeg MD, Goebel JA. Migraine-associated dizziness: patientcharacteristics and management options. Otol Neurotol 2002; 23: 364-71.

23. Salmito MC, Duarte JA, Morganti LO, Brandão PV, Nakao BH, Villa TR, et. al. Prophylactic treatment of vestibular migraine. Braz J Otorhinolaryngol 2017; 83: 404-10.

24. Johnson GD. Medical management of migraine-related dizziness and vertigo. Laryngoscope 1998; 108: 1-28.
25. Baier B, Winkenwerder E, Dieterich M. "Vestibular migraine": Effects of prophylactic therapy with various drugs. A retrospective study. J Neurol 2009; 256: 436-42.

26. Celiker A, Bir LS, Ardiç N. Effects of valproate on vestibular symptoms and electronystagmographic findings in migraine patients. Clin Neuropharmacol 2007; 30: 213-21.

27. Carmona S, Settecase N. Use of topiramate (Topamax) in a subgroup of migraine-vertigo patients with auditory symptoms. Ann N Y Acad Sci 2005; 1039: 517-20.

28. Bisdorff AR. Treatment of migraine related vertigo with lamotrigine an observational study. Bull Soc Sci Med Luxembourg 2004; 2: 103-8.

29. Dolly 0. Synaptic transmission: inhibition of neurotransmitter release by botulinum toxins. Headache 2003; 43: 16-24.

30. Aoki KR. Pharmacology and immunology of botulinum neurotoxins. Int Ophtalmol Clin 2005; 45: 25-37.

31. Gazerani P, Pedersen NS, Staahl C, Drewes AM, Arendt-Nielsen L. Subcutaneous Botulinum toxin type A reduces capsaicin-induced trigeminal pain and vasomotor reactions in human skin. Pain 2009; 141: 60-9.

32. Cernuda-Morollon E, Ramon C, Larrosa D, Alvarez R, Riesco N, Pascual J. Long-term experience with onabotulinumtoxinA in the treatment of chronic migraine: What happens after one year?. Cephalalgia 2015; 35: 864-8. 